\title{
Tingkat Pengenalan Masyarakat Terhadap Jenis Tumbuhan Obat Di Kecamatan Peusangan Selatan Kabupaten Bireun
}

\author{
Saudah $^{1}$, Saida Rasnovi ${ }^{2}$, Zumaidar ${ }^{3 *}$ \\ ${ }^{1}$ Mahasiswa Magister Biologi FMIPA Universitas Syiah Kuala, Banda Aceh \\ 2,3 Jurusan Biologi FMIPAUniversitas Syiah Kuala, Banda Aceh \\ *Koresponden email:zumaidar@unsyiah.ac.id
}

Diterima: 28 Desember 2018

Disetujui: 28 Januari 2019

\begin{abstract}
The level of community recognition of medicinal plants in the Peusangan Selatan district of Bireun Regency is still low and has not been scientifically validated. This study aims to know about the community knowledge in used plant as traditional medicine. The method used in data collection is Participatory Rural Appraisal (PRA) and observation techniques. Inter-views were conducted semi-structurally based on a number of questionnaires. Collection of plant specimens is taken di-rectly from the location of growth assisted by the respondent or community. Primary data obtained from interviews were tabulated and then analyzed descriptively and presented in tables and figures. The results of the study obtained 23 species of medicinal plants that were grouped into 13 family. The most of plant used are from the Zingiberaceae and Apiaceae. Percentage of plant species that are often used based on community knowledge are Curcuma longa, Carica papaya, Jatropa curcas, Lowsoniaenermis.
\end{abstract}

Keywords: recognition of medical plants, herb medicine, Peusangan Selatan District

\begin{abstract}
Abstrak
Tingkat pengenalan masyarakat terhadap jenis tumbuhan obat di kecamatan Peusangan Selatan Kabupaten Bireun hingga saat ini masih rendah dan belum tervalidasi secara ilmiah.Penelitian ini bertujuan untuk mengiventarisasikan pengetahuan masyarakat dalam pengenalan tumbuhan yang digunakan sebagai obat tradisional.Metode yang digunakan dalam pengumpulan data adalah teknik Participatory Rural Appraisal (PRA) dan observasi.Wawancara dil-akukan secara semi struktural yang berpedoman pada sejumlah daftar pertanyaan.Pengumpulan spesimen diambil lang-sung dari lokasi tumbuhnya, dibantu oleh responden atau masyarakat untuk kemudian di buat spesimen dan di indetifi-kasi.Data primer yang diperoleh dari hasil wawancara ditabulasi dan kemudian dianalisis secara deskriptif dan disajikan dalam bentuk tabel dan gambar. Hasil penelitian diperoleh 23 jenis tumbuhan yang tersebar kedalam 13 suku digunakan olaeh masyarakat di Kecamatan Peusangan Selatan untuk obat trdisional.Jenis tumbuhan yang peling banyak digunakan berasal dari suku Zingiberaceae dan Apiaceae.Persentase jenis tumbuhan yang sering digunakan berdasarkan pengenalan dan pengetahuan masyarakat adalah Curcuma longa, Carica papaya, Jatropha curcas, Lawsonia inermis.
\end{abstract}

Kata Kunci: pengenalan tumbuhan obat, jenis tumbuhan obat, Peusangan Selatan.

\section{Pendahuluan}

Indonesia merupakan negara yang kaya akan sumber bahan obat alam dan obat tradisional yang telah digunakan secara turun temurun. Sekitar 30.000 jenis tumbuhan yang terdata di Indonesia 9.606 jenis $(32,2 \%)$ merupakan tumbuhan obat. Kekayaan biodiversitas dan iklim yang memungkinkan tumbuhan untuk tumbuh sepanjang tahun, sosial budaya masyarakat yang sudah terbiasa memanfaatkan tumbuhan obat dan bahan baku yang mudah diperoleh merupakan peluang besar dalam pengembangan tumbuhan obat di Indonesia (Kardinan dan Dhalimi, 2003).

Pemanfaatan tumbuhan sebagai obat terus meningkat dengan adanya kesadaran masyarakat akan kembali ke alam (back to Nuture). Tumbuhan obat merupakan tumbuhan yang salah satu atau seluruh bagian tumbuhan mengandung zat aktif yang berkhasiat untuk obat.

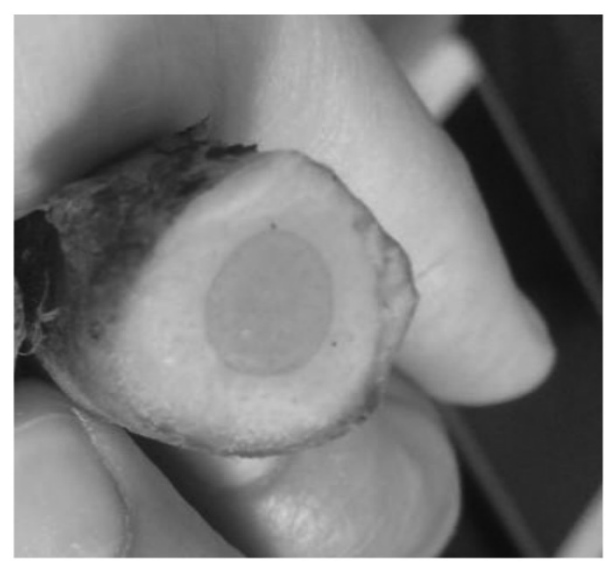

Gambar 1. Curcuma longa (kunyit) 
Tabel 1. Total pengetahuan masyarakat tentang tumbuhan sebagai obat tradisional

\begin{tabular}{|c|c|c|c|c|}
\hline Family & Nama Latin & Nama Daerah & $\begin{array}{c}\text { Total Pengetahuan } \\
\text { Responden }\end{array}$ & $\begin{array}{c}\text { Persentase } \\
\text { Pengetahuan } \\
(\%)\end{array}$ \\
\hline \multirow[t]{2}{*}{ Alliaceae } & Allium sativum & Bawang putih & 38 & 5.69 \\
\hline & Allium cepa & bawang merah & 24 & 3.59 \\
\hline \multirow[t]{4}{*}{ Apiaceae } & Coriandrum sativum & Ketumbar & 28 & 4.19 \\
\hline & Nigella sativa & Jeura hitam & 13 & 1.94 \\
\hline & Curminum сутіпит & Jeura puteh & 5 & 0.74 \\
\hline & Pimpinella anisum & Jira maneh & 14 & 2.09 \\
\hline \multirow[t]{2}{*}{ Asteraceae } & Blumea balsamifera & On Capa & 35 & 5.23 \\
\hline & Elephantopus scaber & Tutup bumi & 12 & 1.79 \\
\hline Caricaceae & Carica Papaya L & On peutek & 68 & $10.1^{*}$ \\
\hline Euphorbiaceae & Jatropha curcas $\mathrm{L}$ & On lawah & 49 & $7.33 *$ \\
\hline Lythraceae & Lawsonia inermis L. & On kaca & 60 & 8.99* \\
\hline Myristicaceae & Myristica fragrans & Pala & 34 & 5.08 \\
\hline \multirow[t]{2}{*}{ Piperaceae } & Piper retrofactum & Cabe jawa & 6 & 0.89 \\
\hline & Piper nigrum Bery. & Lada & 9 & 1.34 \\
\hline Rubiaceae & Morinda citrifolia & Mengkudu & 7 & 1.04 \\
\hline Rutaceae & Citrus aurantifolia & Jeruk nipis & 54 & 8.08 \\
\hline Salicaceae & Salix babylonica & Jaloh & 22 & 3.29 \\
\hline \multirow[t]{6}{*}{ Zingiberaceae } & Alpina galangan & Lengkuas & 26 & 3.89 \\
\hline & Curcuma mangga & Kunyit ketumbu & 8 & 1.19 \\
\hline & Curcuma longa & Induk kunyit & 80 & $11.9 *$ \\
\hline & Curcuma pallida & Kunyit cina & 3 & 0.44 \\
\hline & Zingiber cassumunar Roxb & Kunyit molay & 5 & 0.74 \\
\hline & Zingiber officinale Roscoe & Jahe & 39 & 5.83 \\
\hline
\end{tabular}

*Jenis tumbuhan yang paling banyak digunakan dalam pengobatan

Tumbuhan obat tradisional adalah spesies tumbuhan yang dipercaya oleh masyarakat mempunyai khasiat obat dan telah digunakan sebagai bahan baku obat (Abdiyani, 2008). Pemanfaatan tumbuhan sebagai obat digunakan oleh masyarakat untuk mengobati berbagai penyakit, baik penyakit ringan maupun penyakit menahun.Keuntungan obat tradisional yang dirasakan langsung oleh masyarakat adalah kemudahan dalam memperolehnya dan bahan baku dapat ditanam di pekarangan sendiri.

Pengetahuan masyarakat tentang penggunaan tumbuhan sebagai obat merupakan salah satu pengetahuan yang diturunkan secara turun temurun sebagai bentuk interaksi antara masyarakat dengan lingkungannya. Penggalian potensi pengetahuan lokal masyarakat tentang tumbuhan yang berkhasiat obat dapat memberikan informasi baru dalam memilih bahan baku obat.

Pelayanan kesehatan di Indonesia semakin berkembang namun jumlah masyarakat yang menggunakan tumbuhan dalam pengobatan tradisional tetap tinggi. Menurut survey Sosial Ekonomi nasional tahun 2001, sebanyak 57,7\% penduduk di Indonesia melakukan pengobatan sendiri tanpa bantuan medis dengan memilih pengobatan tradasional sebagai alternatif dalam pengobatan seperti yang dilakukan masyarakat di Kabupaten Bireun.

Kecamatan Peusangan Selatan, Kabupaten Bireun merupakan salah satu kabupaten yang terdapat di Provinsi Aceh. Masyarakat di Kecamatan Peusangan Selatan, Kabupaten Bireun hingga saaat ini masih menggunakan tumbuhan sebagai obat tradisional dalam, mengobati berbagai penyakit. Pengolahan tumbuhan sebagai obat dilakukan dengan cara sederhana dengan menggunakan takaran sejumput, seruas, sebatang, dan selembar. Akan tetapi pengenalan tumbuhan sebagai obat tradisonal pada masyarakat di Kabupaten Bireun masih sangat rendah, sehingga perlu dilakukan penelitian tingkat pengenalan masyarakat tentang 


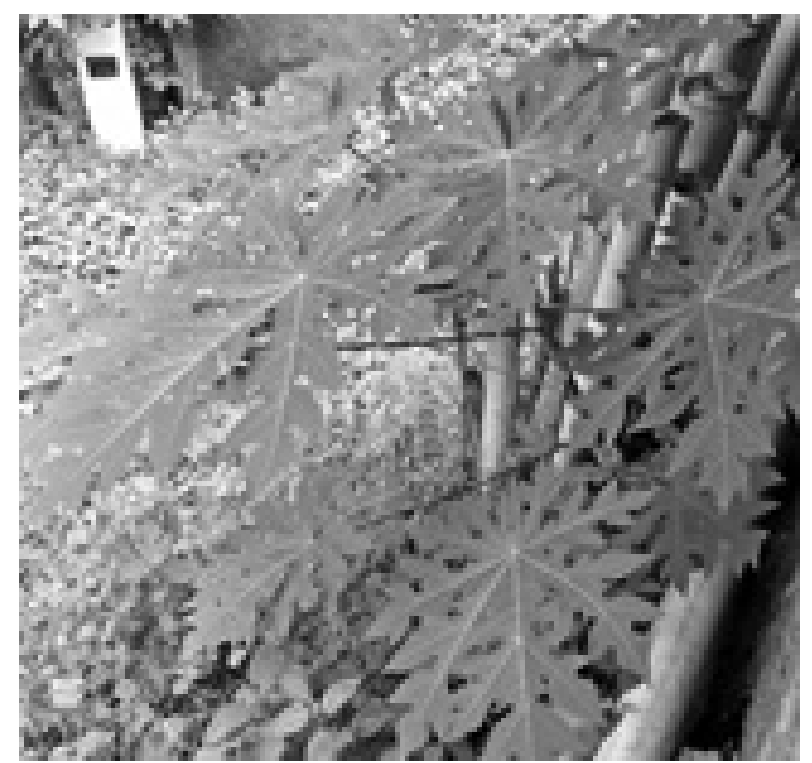

Gambar 2. Carica papaya (daun kates)

pemanfaatan tumbuhan sebagai obat tradisional.

\section{Metodologi Penelitian \\ 2.1 Bahan dan Alat}

Bahan yang digunakan dalam penelitian ini antara lain kamera, alat perekam suara, peta lokasi penelitian, oven, press spesimen, sasag, gunting tanaman, cutter, botol spray, botol koleksi, kantong plastik, tali raffia, selotip, kertas label, daftar pertanyaan, log book, buku tulis, pulpen, pensil, spidol, penggaris, kertas koran, alkohol 70\%.

\subsection{Cara Kerja}

\section{a. Penentuan Lokasi}

Penelitian dilakukan di desa pada Kecamatan Peusangan Selatan, Kabupaten Bireun.Desa yang dipilih adalah sebanyak 6 desa dari $30 \%$ total jumlah desa yang ada di Kecamatan Peusangan Selatan Kabupaten Bireuen.

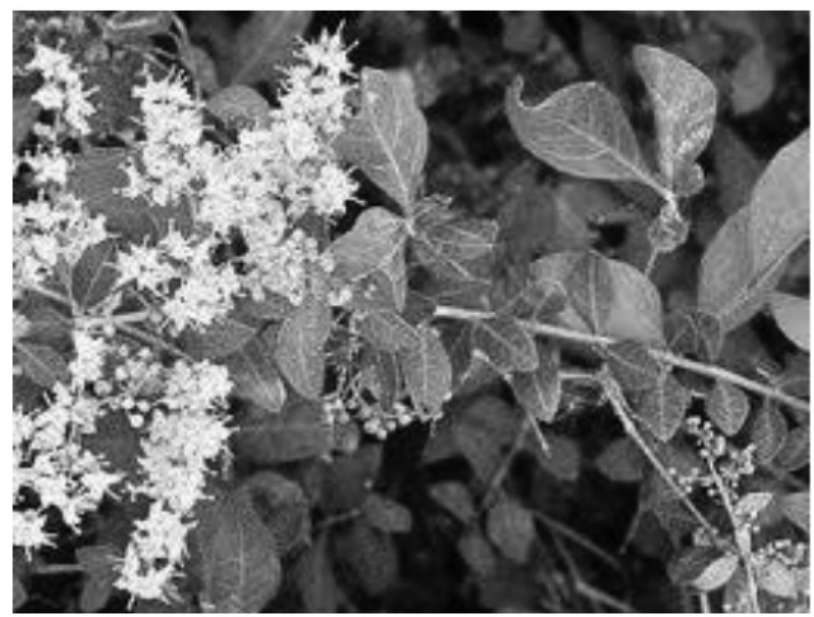

Gambar 3. Lawsonia inermis (inai)

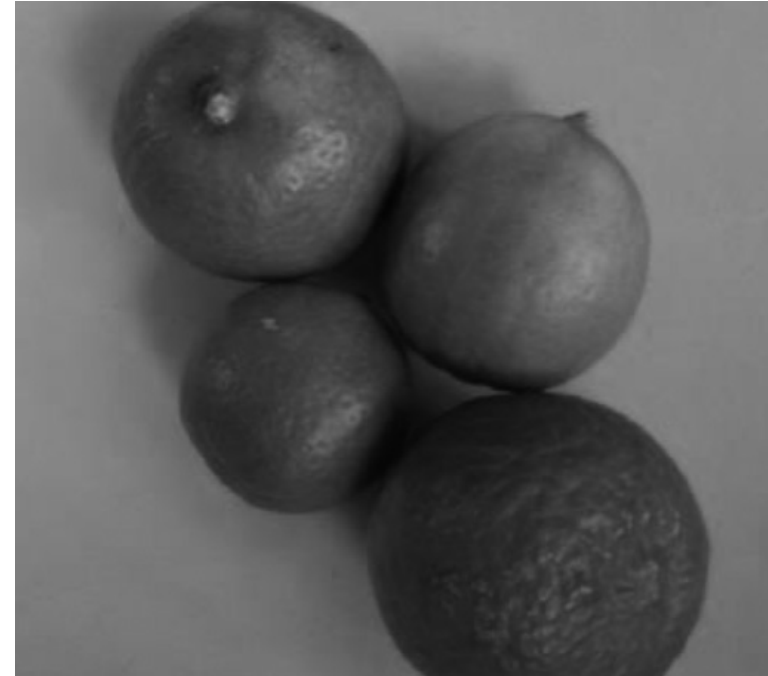

Gambar 4. Citrus aurantifolia (jeruk nipis)

\section{b. Pemilihan Responden}

Metode yang digunakan dalam pengumpulan data adalah teknik Participatory Rural Appraisal (PRA) dan observasi.Wawancara dilakukan secara semi struktural yang berpedoman pada sejumlah daftar pertanyaan. Responden dibagi ke dalam 3 (tiga) kelompok, terdiri atas pengobat (responden kunci), ibu-ibu yang berusia $\geq 45$ tahun ke atas, remaja dan dewasa. Wawancara diarahkan pada sejumlah pertanyaan menyangkut jenis tumbuhan dan pemanfaatan dalam pengobatan.Jenis tumbuhan yang tidak diketahui dan disebut oleh responden dikoleksi untuk selanjutnya dibuat spesimen herbarium dan diindentifikasi lebih lanjut.

\section{c. Pengumpulan Spesimen}

Pengumpulan spesimen diambil langsung dari lokasi tumbuhnya, dibantu oleh responden atau masyarakat yang mengetahui tumbuhan obat yang dimaksud. Spesimen yang dikoleksi, didokumentasikan untuk

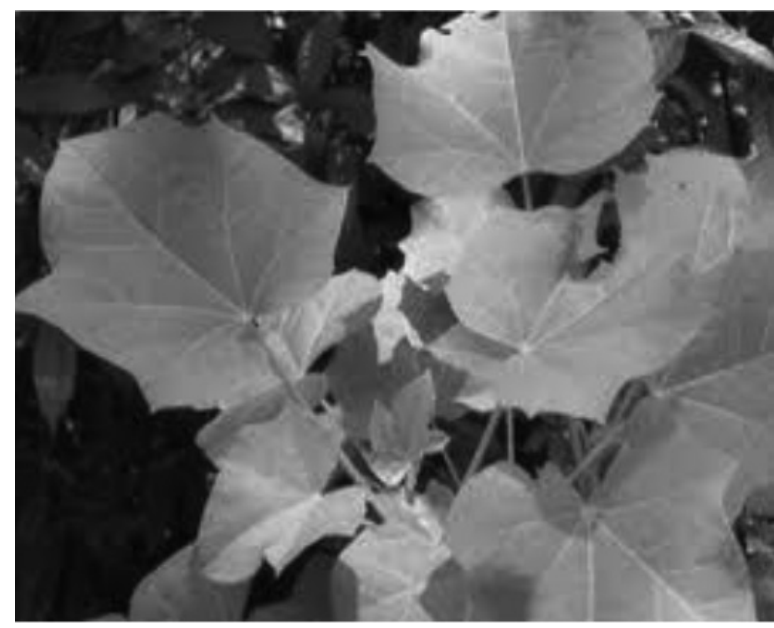

Gambar 5. Jantropha curcas (jarak pagar) 


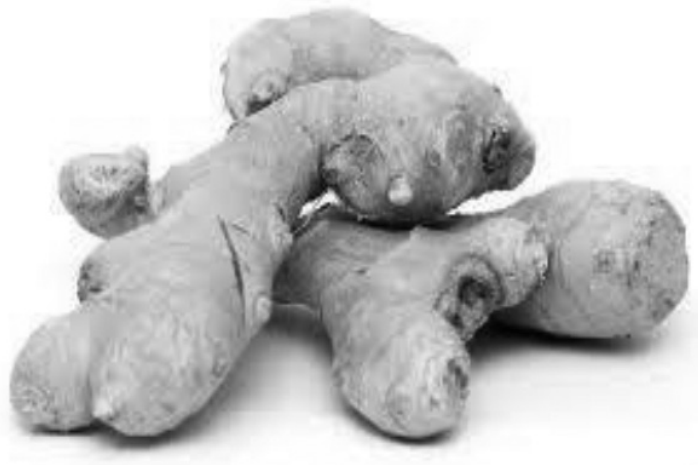

Gambar 6. Zingiber officinale Roscoe (jahe)

selanjutnya diidentifikasi.Untuk tumbuhan yang belum diketahui secara ilmiah dilakukan identifikasi lebih lanjut.Tumbuhan yang diambil dari lapangan diupayakan mempunyai bagian yang lengkap yaitu, batang, daun, bunga dan buah. Spesimen herbarium dipotong dengan ukuran kira-kira $30 \mathrm{~cm}$, diberi label gantung, (berisi nomor koleksi dan kolektor). Selanjutnya specimen herbarium ditata di atas koran, dimasukkan ke dalam kantong plastik, lalu disiram alkohol $70 \%$ hingga merata. Kemudian spesimen herbarium tersebut dibawa ke Herbarium Acehense Jurusan Biologi FMIPA Unsyiah.

\section{d. Analisis data}

Data primer yang diperoleh dari hasil wawancara dengan narasumber tentang penggunaan jenis tumbuhan obat ditabulasi dan kemudian dianalisis secara deskriptif yang disajikan dalam bentuk tabel dan gambar.

\section{Hasil dan Pembahasan}

\subsection{Jenis Tumbuhan yang digunakan oleh masyarakat} sebagai obat

Jumlah responden yang berperan aktif dalam memberikan informasi data adalah sebanyak 95

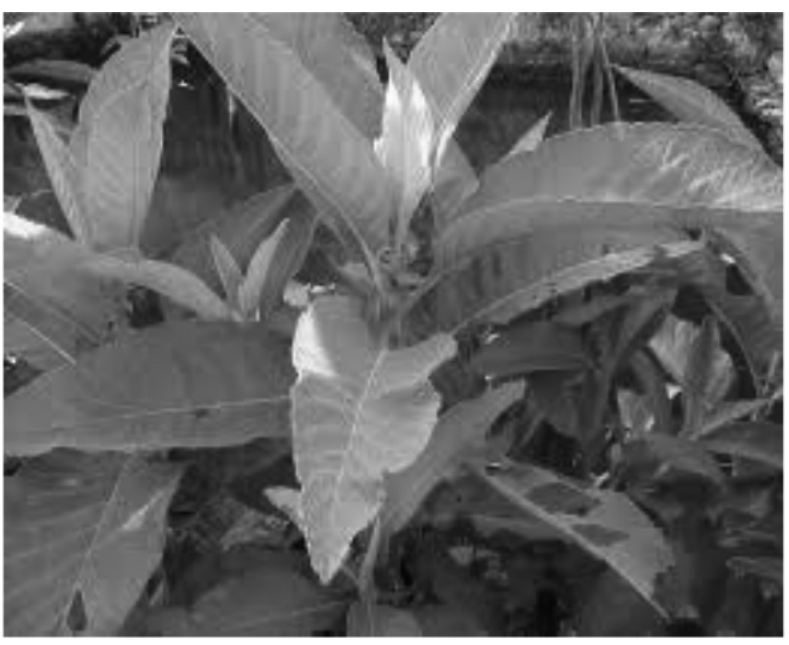

Gambar 8. Blumea balsimifera (Capa)

responden yang menggunakan tumbuhan sebagai obat tradisional. Sebagian responden memberikan informasi lebih dari satu jenis tumbuhan yang digunakan dalam pengobatan.Jenis tumbuhan yang banyak dimanfaatkan sebanyak 23 jenis yang tersebar kedalam 13 suku (Tabel 1.). Jenis tumbuhan yang digunakan sebagai obat berasal dari suku Zingiberaceae (6 jenis), Apiaceae (4 jenis), selebihnya terdiri dari dua atau bahkan satu jenis. Jenis tumbuhan yang paling banyak digunakan berasal dari suku Zingiberaceae dan Apiaceae.

Suku Zingiberaceae dalam kehidupan sehari-hari dikenal sebagai bumbu masak dan dalam pengobatan tradisional secara turun-temurun dipercaya sebagai obat (Pramesti et al., 2012). Secara tradisional, Zingiberaceae telah lama digunakan sebagai anti bakteri, anti inflamsi, analgesik. Selain itu, tumbuhan dari suku Zingiberaceae juga memiliki aktivitas sebagai anti okasidan. Kemampuan anti oksidan dari tumbuhan Zingiberaceae dikarekan adanya kandungan metabolit sekunder seperti flavonoid (Wandita et al, 2018).

Tumbuhan dari suku Apiaceae dikenal oleh

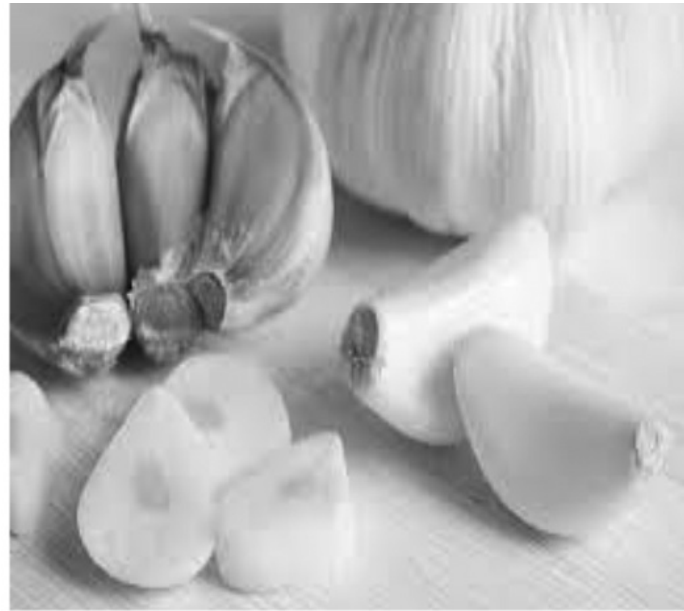

Gambar 7. Allium sativum (bawang putih)

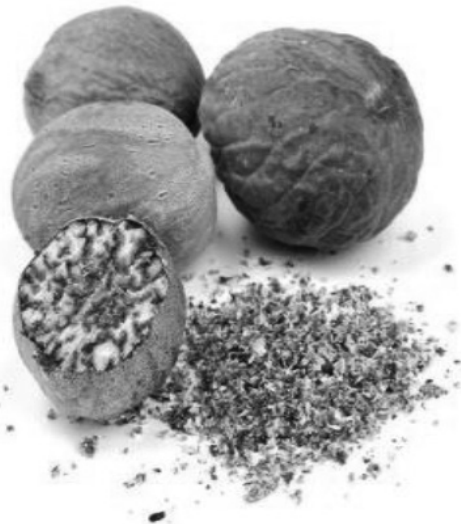

Gambar 9. Myristica fragrans (pala) 


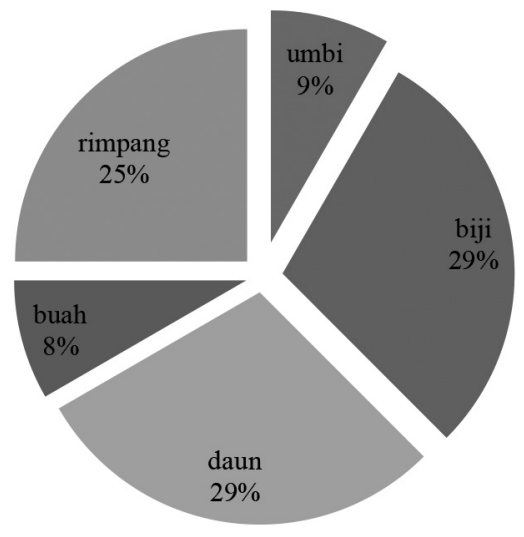

Gambar 10. Bagian yang digunakan dalam ramuan obat

masyarakat sebagai rempah atau bumbu masak dalam kehidupan sehari-hari, selain dijadikan rempah, jenis ini juga banyak digunakan dalam ramuan obat tradisional.Khasiat dari tumbuhan ini adalah menghangatkan badan, menghilangkan sakit kepala, melancarkan peredaran darah, meningkatkan nafsu makan, meluruhkan dahak dan merangsang produksi
ASI. Kandungan bioaktif suku Apiaceae adalah minyak atsiri (Murrat dan Fevzi, 2015).

\subsection{Tingkat Pengetahuan Masyarakat Tentang Tumbuhan Sebagai Obat}

Tingkat pengenalan dan pengetahuan masyarakat tetang penggunaan tumbuhan sebagai obat di Kecamatan Peusangan Kabupaten Bireun, dapat dilihat pada Tabel 1. Persentase penggunaan jenis tumbuhan yang paling banyak digunakan berdasarkan pengetahuan responden adalah Curcuma longa, Carica papaya, Lawsonia inermis, Citrus aurantifolia dan Jatropha curcas. Pengetahuan masyarakat tentang penggunaan tumbuhan obat adalah berdasarkan warisan nenek moyang yang diwariskan secara turuntemurun dalam tingkat keluarga.

Curcuma longa (kunyit) merupakan jenis tumbuhan yang sering digunakan oleh masyarakat dalam pengobatan tradisional.Bagian utama yang digunakan adalah rimpang. Masyarakat di Kecamatan Peusangan banyak menggunakan rimpang C. longa

Tabel 2. Bagian tumbuhan yang digunakan dalam pengobatan tradisional

\begin{tabular}{|c|c|c|c|}
\hline Family & Nama Latin & Nama Daerah & Bagian yang Digunakan \\
\hline \multirow[t]{2}{*}{ Alliaceae } & Allium sativum & Bawang putih & Umbi \\
\hline & Allium cepa & bawang merah & Umbi \\
\hline \multirow[t]{4}{*}{ Apiaceae } & Coriandrum sativum & Ketumbar & Biji \\
\hline & Nigella sativa & Jeura hitam & Biji \\
\hline & Curminum cyminum & Jeura puteh & Biji \\
\hline & Pimpinella anisum & Jira maneh & Biji \\
\hline \multirow[t]{2}{*}{ Asteraceae } & Blumea balsamifera & On Capa & Daun \\
\hline & Elephantopus scaber & Tutup bumi & Daun \\
\hline Caricaceae & Carica Papaya L & On peutek & Daun \\
\hline Euphorbiaceae & Jatropha curcas L & On lawah & Daun \\
\hline Lythraceae & Lawsonia inermis L. & On kaca & Daun \\
\hline Myristicaceae & Myristica fragrans & Pala & Biji \\
\hline \multirow[t]{2}{*}{ Piperaceae } & Piper retrofactum & Cabe jawa & Biji \\
\hline & Piper nigrum Bery. & Lada & Biji \\
\hline Rubiaceae & Morinda citrifolia & Mengkudu & Daun dan buah \\
\hline Rutaceae & Citrus aurantifolia & Jeruk nipis & Buah \\
\hline Salicaceae & Salix babylonica & Jaloh & Daun \\
\hline \multirow[t]{6}{*}{ Zingiberaceae } & Alpina galangan & Lengkuas & Rimpang \\
\hline & Curcuma mangga & Kunyit ketumbu & Rimpang \\
\hline & Curcuma longa & Induk kunyit & Rimpang \\
\hline & Curcuma pallida & Kunyit cina & Rimpang \\
\hline & Zingiber cassumunar Roxb & Kunyit molay & Rimpang \\
\hline & Zingiber officinale Roscoe & Jahe & Rimpang \\
\hline
\end{tabular}


sebagai obat lambung, sakit kepala, pilek dan juga untuk pasca melahirkan. penggunaan rimpang $C$. longa oleh masyarakat dilakukan secara sederhana, misalnya untuk pengobatan sakit kepala rimpang kunyit di tumbuk dan di tempel dibagian kening. Rimpang C. longa berkhasiat sebagai obat demam, pelancar haid, penyembuh luka dan obat mencret. Perasan dari rimpang kunyit dengan penambahan kuning telur atau madu digunakan oleh masyarakat TN Alas Purwo untuk mengobati penyakit maagh (Yuliani et al, 2014).

Kandungan kimia yang terdapat pada rimpang C. longa adalah kurkumin, minyak atsiri, resin, demotoksikurkumin dan lainnya.kandungan kurkumin di dalam rimpang $C$. longamemiliki aktivitas antiokasidan yang efektif dalam sistem emulsi asam linoleat (Shan dan Yoppi. 2018). Kurmin juga mempunyai aktivitas protektif terhadap perlukaan lambung (Prasad et al., 2017)

Carica papaya (daun pepaya) merupakan jenis tumbuhan yang umumnya digunakan oleh masyarakat baik dikonsumsi secara langsung dalam bentuk lalapan atau dalam bentuk perasan. Daun pepaya yang digunakan bentuk lalapan dapat menambah nafsu makan, selain itu perasan dari daun pepaya muda juga dijadikan sebagai obat sakit perut dan diare, demam, kurang darah dan malaria.Komponen bioaktif utama dari C. papaya yaitu, papain dan chymopapain digunakan sebagai bahan tekstil,sedangkan komponen bioaktif sepeti flavonoid, alkaloid dan fenol digunakan untuk mengobati demam malaria (Ayoola et al., 2007). Daun pepaya mengandung protein yang tinggi, lemak, vitamin, kalsium $(\mathrm{Ca})$ dan zat besi $(\mathrm{Fe})$ yang berfungsi sebagai pembentukan hemoglobin (Tietze, 1997).

Lawsonia inermis (inai) merupakan jenis tumbuhan yang pada umumnya digunakan oleh masyarakat di Kabupaten Peusangan Selatan sebagai hennaatau pewarna kuku dan sesejuk dalam prosesi adat masyarakat.

Masyarakat di Desa Pesaguan Kanan Kecamatan Matan Hilir Selatan Kabupaten Ketapang memanfaatkan $L$. inermis sebagai tumbuhan penghasil warna alami (Lyananti et al., 2015). Selain digunakan dalam upacara adat istiadat, jenis tumbuhan ini juga digunakan dalam pengobatan tradisional untuk mengobati lambung dan juga campuran obat pasca melahirkan. qL. inermis mempunyai khasiat sebagai antimikroba, antiokasidan, anti inflamasi, anlagetik dan antiperatik. Kandungan senyawa aktif dalam L. inermis seperti alkaloid, glikosida, falvonoid, fenol,saponi, tannin, dan minyak atsiri (Hasiani et al.,2015).

Citrus aurantifolia (jeruk nipis) merupakan jenis tumbuhan obat yang umum digunakan dalam pengobatan tradisional di Kecamatan Peusangan, Kabupaten Bireun. Masyarakat sering menggunakan C. aurantifolia untuk mengobati batuk, gatal kerongkongan dan juga untuk campuran ramuan lainnya. Citrus aurantifolia atau disebut juga jeruk nipis adalah tanaman dari family Rutaceae yang banyak dibudidayakan dibagian dunia karena kualitas gizi dan bermanfaat banyak untuk kesehatan. Buah adalah bagian yang sering digunakan dalam pengobatan. Secara tradisional Citrus aurantifolia digunakan sebagai obat antiseptic, antivirus, antijamur, anthelmintik, astrigen, diuretic, penyakit perut, sembelit, sakit kepala, radang sendi, pilek, batuk, sakit tenggorokan dan sebagai penambah nafsu makan. Kandungan fitokimia dari Citrus aurantifolia adalah flavanoid, limonoid, fenol, karotenoid, mineral dan vitamin (Onyilofe. et al.2015).

Masyarakat di Kecamatan Peusangan Selatan juga memanfaatkan Jatropha curcas(jarak pagar) sebagai obat tradisional. Jenis ini banyak digunakan untuk mengobati kembung, sakit perut, sakit gigi, dan luka. Daun dan ranting jarak mengandung flavonoid, apigenin, vitexin dan isovitexin.Flavonoid yang terkandung dalam ekstrak kulit batang jarak memiliki aktifitas antimikroba, anti alergi dan antiokasidan (Napanggala et al., 2014).

Selain daun jarak masyarakat juga menggunakan getah jarak sebagai alternatif untuk mengobati sakit gigi.Secara tradsional masyarakat menggunakan getah jarak yang diambil langsung dari batang dan dioleskan pada gigi yang sakit.Getah jarak mengandung zat anitmikroba yaitu saponin, tannin dan falvonoid. Getah jarak digunakan sebagai obat pada karies gigi dengan cara meneteskan getah sebanyak satu atau dua tetes kedalam lubang gigi (Irmaleny et al., 2010).

Zingiber officinale Roscoe (jahe) merupakan jenis tumbuhan obat dari suku Zingiberaceae yang umum digunakan sebagai rempah dan juga sebagai obat. Dalam pengobataan tradisional jahe digunakan sebagai obat dalam bentuk ramuan tunggal maupun campuran. Secara tunggal Z. officinale digunakan untuk mengobati kembung, masuk angin, demam dan sakit gigi. Bagian yang sering digunakan adalah rimpang. Komponen utama pada rimpang jahe memiliki manfaat sebagai obat. Studi pra-klinis rimpang jahe bermanfaat dalam perawatan diabetes, obesitas, diare, alergi, nyeri, demam, peradangan dan berbagai bentuk kanker. Rimpang jahe mengandung minyak atsiri, terdiri atas senyaw-senyawa aktif seperti $\beta$-bisabolene, $\beta$-farnesene, sequiphelandrene, zingiberen, zingeron, oleoresin, kafena, sineol, senyawa fenolik, flavonoid, karohidrat, protein, 
alkaloid, glikosida, saponin, steroid, terpenoid dan tannin sebagai kelompok utama fitokimia (Hanief, 2013).

Allium sativum atau bawang putih, merupakan jenis tumbuhan dari suku Alliaceae yang banyak digunakan dalam bumbu masakan atau obat herbal. Dalam pebgobatan tradisional jenis ini umum digunakan oleh masyarakat di Kecamatan Peusangan Selatan Kabupaten Bireun untuk mengobati bisul, darah tinggi dan kolesterol. Bawang putih memiliki sifat anti-virus, anti-bakteri, antijamur, antiokasidan, anti-aterosklerotik dan anti kanker (Satyanand et al. 2013). Allicin adalah komponen bioaktif utama pada bawang putih yang diduga sebagai antioksidan yang sangat kuat (Rahma. et al. 2012).

Blumea balsimifera (capa) merupakan jenis tumbuhan dari suku Asteracea yang umum digunakan oleh masyarakat di Kecamatan Peusangan Selatan Kabupaten Bireun untuk mengobati nyeri haid, influenza, rematik dan sakit pinggang. Bagian yang sering di gunakan dalam pengobatan tradisional adalah bagian daun. Senyawa kimia yang terkandung pada daun diantaranya borneol, caryophyllene, ledol, tetracyclo, tridecan-9-ol, 4,4-dimethyl, phytol, caryophyllene oxide, guaionol, flavonoid, umberlliferone dan hydranngetin. Tanaman blumea balsimifera adalah tanaman obat yang digunakan dalam pengobatana tradisional seperti beri-beri, sakit pinggang, rematik, cedera kulit atau digunakan untuk insektisida. Secara tradisional ekstrak kasar tumbuhan Blumea balsimifera digunakan untuk antitumor, antiokasidan, antityrosinase, anti mikroba, anti inflamasi dan penyembuh luka (Yuxin P et al 2014).

Myristica fragrans atau disebut juga dengan pala yang berasal dari suku Myristaceae. Jenis ini sering digunakan sebagai rempah atau bumbu masak. Dalam pengobatan tradisional Myristica fragrans digunakan untuk mengobati luka memar, sakit kepala dan masuk angin. Bagian yang sering dalam ramuan obat adalah biji. Kandungan kimia dari biji pala mengandung minyak esensial 10\%, 25-30\% minyak tetap miristat, stearat, palmitat, oleat, asam lonoleat dan asam laurat. Selain itu biji pala mengandung saponin, polifenol, tannin, epikatekin, sapogenin, kalsium, fosfor, besi, tiamin, ribofllafin dan niacin (Reena dan Patil, 2012). Drazat (2007), menyatakan bahwa biji pala dipercaya dapat menghilangkan rasa sakit dan nyeri yang disebabkan oleh kedinginan dan masuk angin. Selain itu manfaat biji pala juga dapat menghilangkan rasa lelah, mengatasi nganguan pada telinga, menghentikan muntah, mengatasi insomnia. Dalam dunia indutri biji pala banyak digunakan sebagai minyak wangi.

\subsection{Bagian Tumbuhan Yang Digunakan Dalam Ramuan Obat}

Pengetahuan masyarakat tentang bagian tumbuhan tumbuhan yang umum digunakan merupang akan warisan dari nenek moyang yang diturunkan dalam tingkat keluarga. bagian daun, umbi, buah dan biji. Bagain yang umumnya digunakan adalah bagian daun (29\%), biji (29\%), rimpang (25\%), umbi $(9 \%)$ dan buah (8\%). Daun dan umbi merupakan bagian yang paling banyak digunakan, selain dari rimpang, umbi dan buah. Bagian daun banyak digunakan dalam pengobtan dikarenakan daun melimpah, mudah di dapat dan dipercaya secara turun temurun digunakan dalam pengobatan tradisional.

Penggunaan bagian daun dari tumbuhan obat tertentu merupakan pengetahuan secara turun temurun yang diperoleh dari nenek moyang. Selain itu, khasiat daun dipercaya secara turun temurun banyak dalam segi penyembuhannya jika dibandingkan dengan bagian lainnya

\section{Kesimpulan}

1. Terdapat 23 jenis tumbuhan yang dikelompokkan kedalam 13 suku, yang dikenal oleh masyarakat di Kecamatan Peusangan Selatan Kabupaten Bireun.

2. Jenis tumbuhan yang banyak digunakan berasal dari suku Zingiberaceae dan Apiaceae.

3. Presentase jenis tumbuhan yang paling banyak digunakan adalah Curcuma longa, Carica papaya, Jatropha curcas, Lawsonia inermis.

\section{Daftar Pustaka}

Abdiyani, S. 2008. Keanekaragaman Jenis Tumbuhan Bawah Berkhasiat Obat di Daratan Tinggi Dieng. Jurnal Penelitian Hutan dan Konservasi Alam, 5 (1): 79-92.

Ayoola, P.B and Adeyeye, A. 2007.Effect of Heating on the Chemical Composition and Physico - Chemical Properties of Arachis hypogea (Groundnut) Seed Flour and Oil. Pakistan Journal of Nutrition. Vol 9(8):751-754.

Hasiani VV, Ahmad I, Rijai L. 2015. Isolasi jamur endofit dan produksi metabolit sekunder antioksidan dari daun pacar (Lawsonia inermis L.).Jurnal Sains dan Kesehatan.;1(4):146-153.

Irmaleny, Sumawinata Narlan, Fatma Dewi, Abdassah Marrline. 2010. Dosis efektif getah jarak pagar (Jatropha curcas $l$ ) sebagai analgesik dengan menggunakan tes geliat. Makassar: Universitas Hasanuddin.

Kardinan, A dan A. Dhalimi. 2003. Mimba (Azadirachta indica) tanaman multimanfaat. Jurnal teknologi perkembangan TRO XV (1). 
Lyananti, P.R., Setia., B dan Fathu, Y. 2015. Studi Etnobotani Tumbuhan Yang Dimanfaatkan Di Desa Pesaguan Kanan Kecamatan Matan Hilir Selatan Kabupaten Ketapang.Jurnal Hutan Lestari, 3(3): 421-433.

Murrat, T and Fevzi, O. 2015. Chemical composition of some Apiaceace palnts commonly used in herby in Eastern Anatolia. Turkish Journal of Agriculture and Forestry, 39: 55-62.

Napanggala A, Susianti, Aprilliana E. 2014. Effect of jatrophas's (Jatropha curcas l) sap topically in the level of cuts recovery on white rats sprague dawley strain. J Majority. 3(5):26-35.

Pramesti, G., F. Arum., A. Retnoningsih dan A. Irsadi. 2012. Etnobotani Tumbuhan Obat Masyarakat Desa Keseneg Kecamatan Sumowono Kabupaten Semarang Jawa Tengah. Unnes Journal of Life Science, 1(2): 12-132.

Prasad, D.N., Gupta, B., Srivastava, R.K., Setyavati, G. V. 1976. Effect of high does of curcumin, Indian J. Phisiol. Pharmacol. 20, p. 92.

Shan, C.Y dan Yoppi, I. 2018. Studi Kandungan Kimia dan Aktivitas Farmakologi Tanaman Kunyit (Curcuma longa L). Farmaka Suplemen, 16(2): 547-555.

Tietze HW. 1997. Tempi Pepaya, buah Terapi Makanan yang Aman dan Murah. Jakarta: Prestasi PustakaRaya.

Wandita, G. A dan Musfiroh, I. 2018.Review Artikel: Tanaman Suku Zingiberaceae Yang Memiliki Aktivitas Sebagai Antiokasidan. Farmaka suplemen. 16(20): 564-571.

Yuliani., Asyiah, I.N dan Hariani, S. A. 2014. Pemanfaatan Famili Zingiberaceae Sebagai Obat Oleh Masyarakat Desa Penyangga Taman Nasional Ala Purwo.Artikel ilmiah hasil penelitian Mahasiswa.

Onyilofe. S.E., Ogunyemi.I. O., Smart Bala. M., Oruene. I.S., Suleiman. M. M., Folorunsho Ambali. S. 2015. Ethnomedical Importance of Citrus Aurantifolia (Christm) Swingle. The Pharma Innovation journal. Vol.4(8): 01-06.

Hanief, S. 2013. Efektivitas Ekstrak Jahe (Zingiber officenale Roscoe) Terhadap Pertumbuhan Bakteri Sterptrococcus viridians. Skripsi. Fakultas Kedokteran dan Ilmu Kesehatan. Universitas Isalm Negeri Syarief Hidayatullah, Jakarta.

Drazat. 2007. Meraup Laba dari Pala. Agromedia Pustaka. Jakarta Selatan. 